\title{
Sleep disorders in high school and pre-university students
}

\author{
Célia R.S. Rocha', Sueli Rossini², Rubens Reimão ${ }^{3}$
}

\begin{abstract}
Adolescence is a period in which youngsters have to make choices such as applying for university. The selection process is competitive, and it brings distress and anxiety, risk factors for the appearance of sleep disorders. Objective: To verify the occurrence of sleep disorders in third-year high school and pre-university students. Method: This cross-sectional descriptive study comprised a sample of 529 students ( $M=241, F=288$ ) from three public schools, four private schools and two pre-university courses - a middle-class neighborhood in the city of São Paulo - aged between 16 and 19 years old. We used the Pittsburgh Sleep Quality Index (PSOl) - a standardized questionnaire. Results: The participants (52.9\%) took about 30 minutes to fall asleep, with an average of 306.4 minutes asleep, moderate daytime sleepiness ( $n=243,45.9 \%$ ) and indisposition ( $n=402,75.9 \%$ ) to develop the activities. The scores ( $\mathrm{M}$ and $\mathrm{F}$ ) were similar regarding problems that affect sleep. Conclusion: The investigated population showed sleep disorders and poor sleep quality.
\end{abstract}

Key words: sleep quality, sleep disorders, adolescents, high school.

\section{Distúrbios do sono em estudantes do ensino médio e curso pré-vestibular}

\section{RESUMO}

A adolescência é tida como um período em que o jovem tem que fazer escolhas; a entrada na universidade é uma delas. O processo seletivo é concorrido, trazendo à tona angústia e ansiedade, fatores de risco para o surgimento de distúrbios do sono. Objetivo: Verificar a ocorrência de distúrbios do sono em estudantes do terceiro ano do ensino médio e de curso pré-vestibular. Método: Foi realizado um estudo transversal, descritivo. A amostra de 529 estudantes $(M=241 ; F=288)$ de três escolas públicas, quatro escolas privadas e dois cursos pré-vestibulares, de um bairro de classe média, da cidade de São Paulo, na faixa etária entre 16 e 19 anos. Utilizou-se o Índice de Qualidade do Sono de Pittsburgh (IQSP) - questionário padronizado. Resultados: Verificou-se que os participantes (52,9\%) levavam cerca de 30 minutos para dormir, com a média de 306,4 minutos dormidos, apresentavam sonolência diurna moderada ( $n=243,45,9 \%)$ e indisposição $(n=402,75,9 \%)$ para desenvolver as atividades. Os escores ( $\mathrm{M}$ e F) são semelhantes, no que se refere aos problemas que influenciam o sono. Conclusão: Existe a ocorrência de distúrbios do sono e má qualidade do sono na população estudada.

Palavras-chave: qualidade do sono, distúrbios do sono, adolescentes, ensino médio.

Correspondence Célia Regina Silva Rocha Rua Paulo Ornellas Carvalho de Barros 98 / 44F 02344-030 São Paulo SP - Brasil E-mail: crsrocha@gmail.com

Received 1 March 2010 Received in final form 8 June 2010 Accepted 15 June 2010
In recent decades, adolescence has been considered a crucial phase of human development, period in which profound both physical and social changes occur, often causing tension, stress and other forms of disorders ${ }^{1}$.
At the same time that youngsters passe through the troubled adolescence, they have to make decisions that will reflect through all their lives. The entrance into the university is one of them; these young people are exposed to uncertainties and

1Ph.D., Psychologist, Program in Child and Adolescent Health, Faculty of Medical Sciences, University of Campinas (UNICAMP), Campinas SP, Brazil; ${ }^{2}$ PhD, Psychologist, Division of Clinical Neurology, Hospital das Clínicas, University of São Paulo Medical School, São Paulo SP, Brazil; ${ }^{3}$ MD, PhD, Pediatric Neurologist, Division of Clinical Neurology, Hospital das Clínicas, University of São Paulo Medical School, São Paulo SP, Brazil. 
conflicts generated by choices, since when they choose a course, they will give up others, even though temporarily.

The students' emotional state changes as well. D'Ávila and Soares ${ }^{2}$ claims that they are more reserved inward looking during the period of university entrance examinations, manifesting feelings of anxiety and distress.

Thus, the physical and social alterations, along with the insertion into the adult world and career choice, make the proximity of the exam, which is a rite of passage in the lives of individuals, one of several risk factors for this group age.

In addition, the possibility and sense of failure related to family and social group's expectations can lead to social isolation and low self-esteem, factors difficult to bear and which lead the adolescent to develop symptoms of depression and sleep disorders ${ }^{1}$.

Since sleep is essential for maintaining the balance of the human psyche, its deprivation causes significant damage to concentration, memory and emotional control.

Nowadays, sleep deprivation in adolescence may occur because of external factors, such as class schedule, nights out with friends, long night hours awake or watching television or surfing the internet ${ }^{3,4}$.

Other factors may contribute to restless sleep: feelings and concerns experienced by youth in the face of pressure from parents and family members to fulfill their obligations, uncertainties relative to school difficulties and the future, which usually are accompanied by bodily changes inherent in the stage of development. However, Carskadon and $A_{c e b o}{ }^{5}$ emphasize that the possibility of these aspects of pubertal maturation influence the behavioral factors responsible for this reorganization is not yet well determined.

During adolescence, the period of sleep varies from 8 hours and 36 minutes to 6 hours and 4 minutes, with an average of seven hours ${ }^{4}$. According to Halbower and Marcus $^{6}$, insomnia is a common sleep disorder in adolescence, with a prevalence ranging from $2.2 \%$ to $17 \%$. Lui et al. ${ }^{7}$ found that $18.8 \%$ of adolescents have poor sleep, difficulty initiating sleep and daytime sleepiness (17.9\%), and that approximately $26.2 \%$ are dissatisfied with their sleep quality.

Adolescents tend to delay the sleep phases, i.e. they prefer to sleep and awake later ${ }^{8,9}$ due to changes in biological rhythms and aspects of individual variability: morning and evening.

In addition to the reported problems, there may be extrinsic sleep disturbances caused by external factors, such as school and family pressure, poor sleep hygiene and sleep deprivation, as well as stimulant and alcohol use. Among them, we can highlight the anxiety caused by the proximity of the university entrance exams, which can be a determining factor for a poor sleep quality.

The aim of this study was to verify the occurrence of sleep disorders in third-year high school and pre-university students.

\section{METHOD}

The survey was conducted in three public schools, four private schools and two pre-university courses in a middle-class neighborhood of São Paulo, comprising a population of 529 students, 451 high school courses and 78 preentrance exam courses, by using a convenience sample.

The inclusion criteria were as follows: age between 16 and 19 years old; be a third-year student in secondary education in a public school, private school or pre-university course; have the written permission from parents or guardians (after clarification); and answer the Pittsburgh Sleep Quality Index (PSQI) ${ }^{10}$.

We conducted a descriptive cross-sectional study by using socio-demographic data, such as type of school (public or private), age, gender, parental education and family income, and by applying the Pittsburgh Sleep Quality Index ${ }^{10}$, which evaluated the sleep-wake cycle pattern (the usual sleeping and waking time).

When answering the standardized questionnaire, which included 19 closed questions to measure and provide information about habits and sleep quality, adolescents reported data on sleeping and waking time during the last month.

The cutoff level was established in five points in order to characterize sleep disorders in students.

The PSQI was initially read along with the students, allowing doubt clarification.

The schools were chosen for convenience, ease access and availability to cooperate with the study. The sample comprised 529 students of both genders: 288 (54\%) females and 241 (45.7\%) males. Among them, 451 were high school and 78 pre-university students aged between 16 and 19 years old.

Considering that PSQI variables are categorical, Chisquare and Fisher's exact tests were applied, as well as the Mann-Whitney test and Spearman's correlation for calculating position measurements. The level of significance was set at 95\% $(\mathrm{p}<0.05)$ for all statistical calculations.

This research project was approved by the Research Ethics Committee Medical Sciences School, University of Campinas (UNICAMP).

\section{RESULTS}

The PSQI was applied in 529 students aged between 16 and 19 years old. The sample was distributed into gender and age, type of school, type of work, and intention to attend university (Table 1). Among them, 303 (57.5\%) of parents and 144 (27.2\%) of mothers completed high school and 169 (31.9\%) mothers completed higher education. The family income of 227 (44\%) students was from 1 to 5 minimum wages, 181 students reported up to three people living at home (34.3\%) and 177 students reported up to four people living at home (33.6\%). 
Table 1. Distribution of absolute and relative frequencies of participants according to gender, age, study time and type of school.

\begin{tabular}{|c|c|c|c|c|c|}
\hline \multirow[b]{2}{*}{ Variable } & \multirow[b]{2}{*}{ Category } & \multirow[b]{2}{*}{ n (\%) } & \multicolumn{2}{|c|}{ Gender } & \multirow[b]{2}{*}{$p^{*}$} \\
\hline & & & Male(\%) & Female(\%) & \\
\hline \multirow[t]{4}{*}{ Age } & 16 & $92(17)$ & 36 (39) & $56(61)$ & \multirow{4}{*}{0.417} \\
\hline & 17 & $218(41)$ & $100(46)$ & $118(54)$ & \\
\hline & 18 & $150(28)$ & $73(49)$ & $77(51)$ & \\
\hline & 19 & $69(13)$ & $35(51)$ & $34(49)$ & \\
\hline High school & & $461(92)$ & $210(45)$ & $251(55)$ & 1 \\
\hline Preparatory course & & $68(7)$ & $31(46)$ & $37(54)$ & 1 \\
\hline \multirow[t]{4}{*}{ Studying time } & Morning & $411(78)$ & $189(46)$ & $230(54)$ & \multirow[t]{2}{*}{0.924} \\
\hline & Afternoon & $18(3)$ & $8(42)$ & $10(58)$ & \\
\hline & Evening & $99(19)$ & $46(47)$ & $53(53)$ & 0.125 \\
\hline & NA & $1(1)$ & $1(1)$ & - & \\
\hline \multirow[t]{3}{*}{ Claim in applying to university } & Yes & $473(90)$ & $216(46)$ & $257(54)$ & \multirow{3}{*}{0.803} \\
\hline & No & $42(7)$ & $18(43)$ & $24(57)$ & \\
\hline & NA & $14(3)$ & $7(50)$ & $7(50)$ & \\
\hline
\end{tabular}

${ }^{*} \mathrm{p}$-value of Chi-Square test; Mann-Whitney test ;NA: not answered.

The characterization and multivariate analysis of the sleep-wake cycle pattern was performed under qualitative and quantitative aspects, using data obtained by the sleep habits questionnaire. The first two topics presented calculations of position measurements (minimum, maximum, median, quartile 1 and quartile 3) and the Mann-Whitney test results, which showed differences between the groups: "good sleepers" and "bad sleepers", and preparatory students and students who did not attend the courses.

In order to verify whether these co-relational results would repeat after dividing participants into "bad sleepers" and "good sleepers", preparatory course students and students who did not attend them were submitted to the Spearman' test.

Most of the 529 students of different age groups who responded to the questionnaires study in the morning, attend high school (77.7\%) and preparation courses (97\%), with percentage varying from $72 \%$ to $87 \%$. Only $73(13.8 \%)$ students attend preparatory courses in parallel to school.

Among the participants, 195 (36.9\%) took about 15 minutes and 172 (32.5\%) from 15 to 30 minutes to sleep. The average sleep duration was 306.4 minutes. The average of those who took longer than 30 minutes to fall asleep varied between 1 and 2.5, with the exception of 16 -year-old girls $(\mathrm{md}=3)$; the average of those who woke up at night or too early varied between 1 and 2.5 , with the exception of 16-year-old girls ( $\mathrm{md}=4$ ) and 19-year-old boys; the average of those who woke up to go to the bathroom varied between 1 and 2.5; the average of those who had trouble breathing was 1 , with the exception of 18 year-old boys $(\mathrm{md}=2)$; the average of those who coughed or snored too loud was 1; the average of those who felt heat and cold and had bad dreams varied between 1 and 3 ; the average of those who suffered pains varied between 1 and 2.5; the sleep quality varied between 3 and 4, the average of those who took sleep medication was 1 for all categories; and the average of those who felt drowsy and unwell varied between 1 and 3 .

The percentage distribution of participants working or not is similar in gender and age categories, although there are some small percentage changes between boys and girls that work or not: $68 \%$ and $73.1 \%$, respectively, do not work. In general, most participants did not work. The exception referred to 17-year-old girls (45.5\%), 16-yearold boys (25\%) and 17-year-old boys (47.5\%).

Most of the students ( $n=456,86.2 \%$ ) did not attend the preparatory course for college entrance exams, and among those who attended preparatory school, the highest percentages were found as follows: 18-year-old boys (33.3\%) and 19- year-old boys (50\%).

Most of the students ( $n=478,92.8 \%$ ) aimed to attend college, and among those who had no such goal were youth aged 18 years old (2.6\%) and 17 years old (2.4\%).

Concerning the PSQI results, sleep disturbances, regardless of gender, indicated that 274 (51.8\%) of participants sleep 6-7 hours, males (6h47) and females (5h36). The average of minutes of sleep per night was 300 minutes, with a minimum of 110 and maximum of 720 minutes.

Respecting the gender, the average was 420 minutes 
Table 2. Standard and quality of sleep according to gender.

\begin{tabular}{|c|c|c|c|c|}
\hline \multirow[b]{2}{*}{ Variable } & \multirow[b]{2}{*}{ Category } & \multicolumn{2}{|c|}{ Gender } & \multirow[b]{2}{*}{$\mathrm{p}^{*}$} \\
\hline & & Female (\%) & Male (\%) & \\
\hline \multirow[t]{4}{*}{ Subjective quality of sleep } & Very good & $45(15.7)$ & $40(16.6)$ & \\
\hline & Good & $173(60.1)$ & $148(61.4)$ & 0.0335 \\
\hline & $\mathrm{Bad}$ & $56(19.4)$ & $44(18.4)$ & \\
\hline & Very bad & $14(4.8)$ & $9(3.7)$ & \\
\hline \multirow[t]{4}{*}{ Sleep latency } & Up to $15 \mathrm{~m}$ & $72(25)$ & $73(30.4)$ & \\
\hline & Between 16-30 m & $162(56.3)$ & $118(48.9)$ & 0.0451 \\
\hline & Between 31-60 m & $38(13.2)$ & $27(11.2)$ & \\
\hline & More than $60 \mathrm{~m}$ & $16(5.5)$ & $23(9.5)$ & \\
\hline \multirow[t]{6}{*}{ Habitual sleep efficiency } & More than 85 & $34(11.8)$ & $27(11.2)$ & \\
\hline & Between 75-84 & $193(67)$ & $175(72.6)$ & 0.1512 \\
\hline & Between 65-74 & $57(19.8)$ & $31(12.9)$ & \\
\hline & Less than 65 & $4(1.4)$ & $8(3.3)$ & \\
\hline & 1 or 2 times per week & $156(54.2)$ & $132(54.8)$ & \\
\hline & 3 times per week & $12(4.2)$ & $4(1.6)$ & \\
\hline \multirow[t]{4}{*}{ Somnolency } & None & $2(0.7)$ & $1(0.4)$ & \\
\hline & Small & $144(50)$ & $146(60.6)$ & 0.2539 \\
\hline & Moderate & $66(22.9)$ & $47(19.5)$ & \\
\hline & A lot & $76(26.4)$ & $47(19.5)$ & \\
\hline
\end{tabular}

*p-value Chi-square test.

Table 3. Distribution of the incidence of frequency sleep complaints (at least once a week).

\begin{tabular}{lc}
\hline Complaints of sleep disorder & $\mathrm{n}(\%)$ \\
\hline $\begin{array}{l}\text { Waking up in the middle of the night } \\
\text { or very early in the morning }\end{array}$ & $141(26.6)$ \\
Waking up to go to the bathroom & $140(26.4)$ \\
Having difficulties to breath & $57(10.8)$ \\
Coughing or snoring & $60(11.3)$ \\
Feeling cold & $156(29.5)$ \\
Feeling hot & $181(34.2)$ \\
Having bad dreams or nightmares & $181(34.2)$ \\
Feeling pain & $107(20.2)$ \\
\hline
\end{tabular}

for boys and 390 minutes for girls, i.e. according to this study, males slept more than females.

The position measurements calculated were similar mainly in categories: wake up to go to the bathroom, difficult breathing, coughing or snoring loudly, feeling very cold, feeling very hot, having bad dreams or nightmares and cramps, with average 1 and maximum and minimum values of 1 and 4, respectively.

The descriptive analysis of the sleep quality had an influence on sleep. Drowsiness and upset symptoms revealed that the scores were similar in various categories.
The exception referred to have bad dreams: the average of 1 for male students and 2 for female students.

Considering people with good sleep as those who had scores up to five in the subtotal PSQI, and those with poor sleep with score at or above six, 378 participants (71.4\%) revealed bad sleep quality.

When comparing the sleep quality of students attending pre-university courses and those who did not attend them, there was no difference in overall score. According Table 2, the averages of subjective sleep quality of students who did not attend pre-university courses were better than the students of pre-university preparatory courses.

There was no statistically significant difference, between the two groups of students, regarding data correlation coefficients: -0.005 ( $\mathrm{p}=0.9062)$ for subjective quality, $0.0467(\mathrm{p}=0.2982)$ for sleep duration, $0.0574(\mathrm{p}=0.2008)$ for normal efficiency, $0.0158(\mathrm{p}=0.7237)$ for sleep disorders, $0.0463(\mathrm{p}=0.3023)$ for use of medication and 0.0798 $(\mathrm{p}=0.0755)$ for daytime sleepiness.

The averages were equal for boys and girls, observing small variations in the minimum and maximum values and dispersion, suggesting that the study participants had poor quality sleep. Although the students' sleep quality has been considered good ( $\mathrm{md}=3.50 \%)$, they had troubles to be awake up to three times a week, while doing 
their activities (236 participants, 44.6\%) and lack of enthusiasm and willingness to develop their daily activities (402 participants, $75.9 \%$ ) (Table 3).

\section{DISCUSSION}

Sleep in children and adolescents usually show changes in a predictable way, with sleep duration decrease with age ${ }^{11}$. In adolescence, environmental factors and experienced stress may alter the regulation and circadian rhythm sleep ${ }^{12}$. Technological advances and lifestyle of modern society are also risk factors for the occurrence of such changes, especially of adolescents in urban centers $^{13,14}$. This research aimed to verify the sleep pattern in third-year high school and pre-university students.

The high prevalence of sleep disorders (88.2\%) found in this study shows that a large number of students (teenagers) probably have some type of sleep disorder. There were no significant differences regarding age, which is consistent with other findings in the literature. The study data showed that most participants studied in the morning and did not perform any paid work and intended to enroll in higher education. The results presented here were in accordance with the findings in the literature ${ }^{4,6}$. In this sample, most students took 30 minutes to fall asleep; while the boys slept about 420 minutes per night, the girls slept 390 minutes, that is, males in this group slept more than females.

Regarding the time remaining asleep, these results differ from those found in a study of 37 adolescents $^{14}$, in which the lack of electricity, was a decisive factor for the presence of longer sleep longer duration among students in the afternoon, as they slept on average $9 \mathrm{~h}$ per night. And they are smaller than the results found by Iglowstein et al. ${ }^{4}$ and Lui et al. ${ }^{7}$ (6:50 a.m. and 6:36 a.m.-respectively). There were no significant differences between ages, corroborating other results ${ }^{1,6}$.

In comparison with the global PSQI score, qualitatively, the sleep of both groups of adolescents was considered bad.

There were no significant differences between ages, except for having bad dreams, which rate was higher among women, corroborating other results ${ }^{6}$.

The quality or sleep disturbances between those who wanted to enroll in higher education, those who did not perform paid work or studied in the morning had no significant variations.

The PSQI subjective data, when comparing the performance of high school and pre-university students, showed that students from public high schools had poor sleep quality when compared with their peers in private schools and preparatory courses.

Other subjective data, such as sleep duration, habitual efficiency, sleep disturbances, medication use and daytime sleepiness, were similar in the different catego- ries. The participants assessed the quality of their sleep as good; however, the records indicated lack of enthusiasm and unwillingness to carry on daily activities.

Hinds et al. ${ }^{11}$, state that the breakage or poor quality sleep, cause increased daytime sleepiness. Although daytime sleepiness, such as partial sleep deprivation has been reported as a characteristic of adolescence ${ }^{3,15}$.

There was a relationship between the minutes of sleep and sleep quality, suggesting that the period of sleep had an impact on subjective sleep quality in participants. The main problem presented by the participants of this study was the 30-minute delay to take to get to sleep. These results were close to the findings ${ }^{3,6}$ thus, we can infer the presence of sleep disorders in students of different levels of education, specifically the high school and pre-university courses.

Peixoto et al. ${ }^{14}$ and Brand et al. ${ }^{12}$ suggest that preventive interventions, may reduce the impact on the teenagers sleep pattern and quality.

Sleep researches in high school students are scarce. The increase in complaints of insomnia in adolescence by parents and professionals should always be evaluated; it may be associated with other emotional or behavioral manifestations, typical of this age group. This study highlighted difficulties in initiating and maintaining sleep pattern; therefore, the sleep quality in participants of this study is bad.

\section{REFERENCES}

1. Bahls SC. Epidemiology of depressive symptoms in adolescents of a public school in Curitiba, Brasil. Rev Bras Psiquiatr 2002;24:63-67.

2. D'Ávila GT, Soares DHP. Vestibular: fatores geradores de ansiedade na "cena da prova". Rev Bras Orient Prof 2003;4:1-2.

3. Mesquita G, Reimão R. Sono na adolescência. In: Reimão R (Ed). Sono atualidades. São Paulo: Associação Paulista de Medicina 2006:34-36.

4. Iglowstein I, Jenni OG, Molinari L, Largo RH. Sleep duration from infancy to adolescence: reference values and generational trends. Pediatrics 2003;111: 302-307.

5. Carskadon MA, Acebo C. Regulation of sleepiness in adolescents: update, insights and speculation. Sleep 2002;25:606-614.

6. Halbower AC, Marcus CL. Sleep disorders in children. Curr Opin Pulm Med 2003;9:471-476.

7. Lui X, Zhoo Z, Jia C, Buysse DJ. Sleep patterns and problems among Chinese adolescents. Pediatrics 2008;121:1165-1173.

8. Wolfson AR, Carskadon MA, Acebo C, et al. Evidence for the validity of a sleep habits survey for adolescents. Sleep 2003;26:213-216.

9. Fischer FM, Nagai R, Teixeira LR. Explaining sleep duration in adolescents: the impact of socio-demografic and lifestyle factors and working status. Chronobiol Int 2008;25:359-372.

10. Buysse DJ, Monk TH, Bernan SR, Kupfer DJ, Reynolds CF. The Pittsburgh Sleep Quality Index: a new instrument for psychiatric practice and research. Psychiatry Res 1989;28:193-213

11. Hinds PS, Hockenberry MJ, Gattuso JS, et al. Dexamethasone alters sleep and fatigue in pediatric patients with acute lymphoblastic leukemia. Cancer 2007; 110: 2321-2330.

12. Brand S, Markus G, Martin H, Beck J, Trachsler EH. Evidence for similarities between adolescents and parents in sleep patterns. Sleep Med 2009;10: 1124-1131.

13. Mindell JA, Meltzer LJ, Carskadon MA, Chervin RD. Developmental aspects of sleep hygiene findings from the 2004 National Sleep Foundation Sleep in America Poll. Sleep Med 2009;10:693-816.

14. Peixoto CA, Silva AG, Carskadon MA Louzada FM. Adolescents living in homes without electric lighting have earlier sleep times. Behav Sleep Med 2009;7:73-80.

15. Hagenauer MH, Perryman J, Lee TM, Carskadon MA. Adolescent changes in the homeostatic and circadian regulation of sleep. Dev Neurosci 2009;31:276-284. 